удк: 94(477.6):316.72:323.1

DOI: $10.26661 /$ zhv-2019-1-53-27

\title{
The imposition of the «Russian world» in Ukraine as a means of deformation of the cultural and national identity of the Ukrainians of the Donetsk region
}

\author{
Y. Sytnyk \\ Zaporizhzhia National University \\ july-don@i.ua \\ ResearcherID: http://www.researcherid.com/rid/C-3758-2019 \\ ORCID: 0000-0002-7912-908X
}

Key words: culture, national identity, Ukrainians, hybrid information technologies, Donetsk region, «russian world», plantings, deformation

\begin{abstract}
The article highlights the process of planting the «russian world» in Ukraine as a means of deforming the cultural-national identity of the Ukrainians of the Donetsk region. It was noticed that not only cultural identity, but also national consciousness, mentality and ethnopsychology of the Ukrainian nation was subjected to deformation. It is noted that one of the most used hybrid information technologies was and remains the doctrine of the «russian world». It is noted that a certain part of ethnic Russian and Russian-speaking Ukrainians, who left the occupied districts of the Donetsk region, are now consciously and actively acquiring Ukrainian cultural and national identity. It was emphasized that within the framework of the modern hybrid war unleashed by the Russian Federation against Ukraine, a whole range of hybrid information technologies is used, in particular the doctrine of the «russian world», which encroaches on all territories where the Russian-speaking population exists. According to numerous statements by the adherents of the «russian world», the most purposeful object of planting the «russian world» was and remains Ukraine. It was summed up that the current situation with the Ukrainian identity in the occupied part of Donbass was only a continuation of the systematic planting of the «russian world» in Ukraine and the deformation of the cultural-national identity of Ukrainians.
\end{abstract}

\section{Насадження «русского мира» в Україні як засіб деформації культурно-національної ідентичності українців Донеччини}

\section{Ю. В. Ситник}

Запорізький національний університет

Ключові слова: культура, національна ідентичність, українці, гібридно-інформаційні технології, Донеччина, «русский мир», насадження, деформація.
У статті висвітлюється процес насадження в Україні «русского мира» як засобу деформації культурно-національної ідентичності українців Донеччини. Зауважено, що деформації піддавалася не лише культурна ідентичність, але й національна свідомість, ментальність й етнопсихологія української нації. Зазначено, що однією з найбільш застосованих гібридно-інформаційних технологій була та залишається доктрина «русского мира». Наголошено, що певна частина етнічних росіян і російськомовних українців, які залишили окуповані райони Донеччини, нині свідомо й активно набувають української культурно-національної ідентичності. Підсумовано, що сучасна ситуація з українською ідентичністю на окупованій частині Донбасу стала лише продовженням системного насадження «русского мира» в Україні та деформації культурно-національної ідентичності українців.
Problem statement. For many years to come, the question of the causes and origins of the Russian-Ukrainian war, launched by the Russian Federation in 2014, will probably remain the main question for Ukrainian historians. And now the question arises in a logical way: would this war be possible if, since 1991, the Donbass had a language, the history of Ukraine (and not the history imposed on us from Moscow), Ukrainian literature, Ukrainian national traditions, heroes and symbols (and not habits are 
brought from Russia, often bordering on the subculture of the criminal world), a civilized, European society (and not a silent «population» with the dominance of criminals, communists and various servants of oligarchs). No doubt not! In the same 2014, it was convincingly demonstrated by those areas of Donbass (usually with the prevailing percentage of rural residents), where Ukrainian customs and traditions prevailed, especially in cultural and national terms. All attempts to impose the «russian world» there failed. But in depressed mining towns and villages, with a significant percentage of lumpenized and denationalized residents, where not only linguistic and cultural, but also moral and mental degradation of the population was observed, favorable conditions were created not only for the arrival of the «russian world», but also for establishing criminal authorities of various kinds of mercenary terrorists (including those from the Caucasus, Buryats, etc.), and then the aggression of the Russian Federation.

The analysis of sources and recent researches. The solution of this topic in a certain way laid in the works of I. Dzuby [16], V. Ivanishin and J. Radevich-Vinnitsky [9], G. Turchenko [1, 10], F. Turchenko and G. Turchenko [11], Yu. Kaganova [8] and so on. To a certain extent, the problems of planting the «Russian world» in Ukraine and the deformation of the cultural-national identity of Ukrainians are considered by such authors as: P. Gaiy-Nyznyk [13; 14], S. Gubsky [18], V. Gudz and T. Troitskaya [7], L. Zaliznyak [12], E. Sverstiuk [2], 0. Sytnyk [4; 5], I. Losev [20], 0. Chirkov [15] and others. However, there is a need for more thorough research of this topic.

The publication's purpose. The goal of the article is to highlight the process of planting the «russian world» in Ukraine as a means of deforming the cultural-national identity of Ukrainians. The immediate tasks are to characterize: the policies of Bolshevik Russia, aimed at deforming not only cultural identity, but also national consciousness, mentality and ethnopsychology of the Ukrainian nation; Moscow's hybrid information technology, among which the doctrine of the «russian world» stands out in particular; consideration of the current situation with the Ukrainian identity in the occupied part of Donbass.

Statement of the basic material. The concept of the «russian world» as the Russian modern imperial geopolitical doctrine emerged during Putin's presidency. In the conditions of the transformation of the Russian Federation into a supplier of raw materials for the West (the construction of a «raw superpower»), for the Russian population it was necessary to ideologically justify the project of liberal reforms. And it was in this vein that the doctrine of the «russian world» was formed, in particular, in the interpretation of P. Schedrovitsky. Since 2000, this doctrine has begun to acquire the character of a large neo-imperial project. A significant role in implanting the ideas of the «russian world» in Ukraine belonged to the Russian Orthodox Church, which in every way promoted its own project of the «Orthodox Russian world» based on the dominance of the Russian language and culture, Russian geopolitics and Orthodoxy. And the origins of this policy were from the time of the Russian autocracy.

Back in 1917, the Russian Provisional Government at any cost tried to leave the industrial Donbass under Russian rule. This land has long been predominantly populated by Ukrainians, who constituted from $2 / 3$ to $3 / 4$ of the local population. Continuing the policy of tsarism and the Provisional Government, the Bolshevik government viewed Ukraine as something under its control, and thought in all-Russian and regional categories [1, p.62]. E. Sverstyuk noted that Bolshevism did not accidentally take root in the Russian Empire, where the person was humiliated by centuries. That is why the emergence of the Communists did not cause decisive resistance. In the Russian Empire for centuries the speech of a bureaucratic lie was cultivated as a speech of despotism. Therefore, the principle of the Bolsheviks «life in a lie» did not cause much resistance in the mass. And in the empire, where total enslavement and slavery persisted for centuries, going into the twentieth century, it was easy to keep this slavery under the fashionable name «communism». Pupils of slaves became ideologues, the deceived people accepted demagogues as a new bosses [2, p.722]. And the blind trust of the Ukrainian patriots to the Russian Social Democrats inevitably led to the complete accession of Bolshevism in Ukraine, first as an ideological phenomenon, and therefore to its gradual penetration into all spheres of public life. The consequences of this for Ukraine were truly tragic and led to the destruction by the Bolsheviks of a large part of the Ukrainian nation, in particular the part that believed them.

E. Chykalenko, in his memoirs, noted that at that time the extreme right, the Black Hundreds, had fought with the Ukrainians, on the basis that in Russia there must be "one king, one faith and one people»; the liberals opposed more delicately, but firmly stood for «united, indivisible Russia» and were afraid of everything that threatens its preservation; and the extreme left vehemently opposed the national movements «in the name of unity to the proletariat» [3, p.301]. As soon as Ukrainians raised their heads and showed even claims only for independent cultural life, then all the Russian parties and trends that were hostile to each other united in the struggle against the Ukrainian move- 
ment, speaking against the Ukrainian united front [4, p.320]. All this led to the further purposeful planting of the «russian world» in Ukraine and the deformation of the cultural and national identity of the Ukrainian Donetsk region.

Already in the autumn of 1917, the Bolsheviks initiated the process of the formation of the Donetsk Republic of Soviets, which led to the emergence in February 1918 of the Donetsk-Krivoy Rog Republic. Moreover, this was initiated by local separatist Bolsheviks and under the auspices of representatives of the Bolshevik center of Petrograd. Creating this and other pseudo-state formations in Ukraine, the Bolsheviks rejected the national principle, based on the territorial-economic. Outside of their attention remained the turbulent process of the national revival of the Ukrainian people, which they perceived as a hostile, counter-revolutionary phenomenon [1, p.62-64]. This was a continuation of the policy of cultural discrimination of Ukrainians, which took place in the Russian Empire, and at the same time the beginning of a particularly active destruction of Ukrainian national identity.

At the beginning of the socialist ideas, and later - the Bolshevik government destroyed almost the entire national identity of Ukraine, which was not previously destroyed by the Russian autocracy. The leaders of the Ukrainian revolutionary movement showed unwillingness to defend the ideas of an independent and independent Ukrainian state. Their policies, instead of purposeful state-building, led the country to ever greater anarchy, which not only excluded the organization of the army, but actually contributed to the decline of the Ukrainian state.

All this not only led to the defeat of the national liberation struggle of 1917-1921, but also led to the further total destruction of Ukrainian identity throughout the existence of the Bolshevik government. And in a natural way, the modern war has become a continuation of the centuries-old expansion of Muscovy, with its imperial creations: autocracy, Bolshevism and Putinism, along with neoshovinism against Ukraine. Already at the beginning of the XXI century, we were faced with the resuscitation of neo-Bolshevism in the form of authoritarian tendencies in modern Russia [5, p.196].

I. M. Dzyuba drew attention to the fact that the aggression of Bolshevik Russia was rather closely intertwined with the performances of the pro-Bolshevik-minded masses in Ukraine. This situation is almost completely repeated in our time, when Putin's Russia similarly inspired the regional elites of South-Eastern Ukraine, who actively acted as the fifth column, inflating anti-Ukrainian sentiments among the population and using various social and economic problems, which she herself created. However, there is a definite difference: now the pro-Moscow «fifth column» in Ukraine does not have such support as in the years of the national liberation struggle of 1917-1921, and Ukraine is no longer defenseless and abandoned by the Western world at that time. In addition, Putin's aggression, unlike the Bolshevik, does not carry any social idea and is based only on the chauvinism of the "russian world» $[6, p .8]$.

Due to a number of destructive and destructive influences on the Ukrainian society, first of all: the actual colonial position in the Russian Empire and the totalitarian repressive system in the Soviet Union, a significant part of Ukrainians was turned into a denationalized mass of the «Russian-speaking population» $[7$, p.36, 37]. In terms of national identity for Ukrainians, the choice was small: either to Russify, or to be always ready to come under the repressive pressure of the authorities. Under such conditions, not only cultural identity, but also national consciousness, mentality and ethnopsychology of the Ukrainian nation were subjected to deformation.

Y. Kaganov expressed the opinion that, despite the tremendous efforts, the Soviet totalitarian system failed to completely destroy the national identity of Ukrainians. The historical fate of Ukraine has shown that terror, deportations, concentration camps are as powerless in the struggle against the carriers of the national idea, as are the tools of psychological and ideological processing that are unprecedented in scale. Therefore, despite all the attempts of the Soviet ideology, there was no complete ousting of the main Ukrainian national values, traditional habits and norms of behavior from the public consciousness [8, p.37]. However, Soviet totalitarianism, and especially the Holodomor of 1932-1933 in a large part of Ukraine, particularly in the Donetsk region, led to the loss of the national identity of the majority of Ukrainians. This, in turn, has become too favorable a factor for the imposition of the «russian world» and the subsequent deformation of the cultural-national identity of Ukrainians.

During the existence of the Soviet Union, the trend of multiethnicity in both Ukraine as a whole and the Donetsk region in particular was strongly emphasized. But, at the same time, all the grounds were created for the dominance of the «Russian-speaking population», which, in its overwhelming mass, was negative to the Ukrainian language, and even hostile $[9$, p.149, 157]. Consequently, all grounds were created for the Russification and denationalization of the Ukrainian nation.

For a long time, South-Eastern Ukraine was perceived as part of the Russian state and not only in 
a political and legal sense (as part of the Russian Empire), but also as a kind of continuation of ethnic Russia. Russian society, in general, stubbornly demonstrates the non-recognition of the existence of Ukrainians as a separate nation. F. Turchenko noted that Moscow considered and continues to consider the assembly of the former Russian empire into one whole as its vocation. This was one of the main tasks of the Russian «development» of the South of Ukraine or, in modern terms, the introduction of the «russian world» here [10, p.300]. Equally, this concerned Eastern Ukraine, which became a kind of springboard for the introduction of the latest Russian technologies of hybrid information warfare. According to F. Turchenko and G. Turchenko, the current Russian-Ukrainian war belongs to this type of armed conflict, which is called «hybrid», «non-linear». In general, the characteristic features of hybrid wars are as follows: aggression without an official declaration of war; concealment by the aggressor country of its participation in the conflict; «Information war» - propaganda and counter-propaganda with the use of «dirty» information technologies; widespread use of the «fifth column» and irregular armed formations (including under the guise of the civilian population). It was also an attempt to misinform not only residents of Ukraine, but also Russian citizens, the world community as a whole [11, c.143]. At the same time, the doctrine of the «russian world» has been and remains one of the most widely used hybrid information technologies.

L. Zaliznyak noted that the aggression of imperial Russia against Ukraine had been preparing for a long time and, quite obviously, was inevitable. Depending on the resistance of the Ukrainians or its absence, it could acquire bloodless forms of neo-colonial economic absorption by Russia, or annexation of the territory, as happened with the Crimea. Armed resistance to the aggressor in the Donbas actually poured into the bloody Ukrainian war of Ukrainians against the Russian occupation of their homeland [12 p.167]. In fact, this is the newest stage of the national liberation struggle of the Ukrainian nation for the preservation of national dignity and its own identity.

The actual follower of the Russian empire in the form of the Russian Federation and today actively pursues expansionist policies, promoting and aggressively propagating the ideas of the so-called «russian world». The destructive and actually treacherous policy of the former (Yanukovich times) Ukrainian government in the humanitarian, linguistic, national and informational spheres, and often the frank pro-Russian policy of individual leaders led to the fact that pro-Russian and anti-Ukrainian chauvinistic ideas were spread quite intensively among the population of the southern and eastern regions of Ukraine. This, in turn, led to the intensification of separatist sentiments in the east of Ukraine, not without frank support from the part of the local population that hoped to become part of «great Russia», which ultimately led to the Russian occupation of the Crimea and part of Donbass. The aggression of Russia against Ukraine clearly demonstrated the cynicism of the authorities of the Russian Federation, which, with the aim of spreading its imperial ideas, is prone to grossly ignore international legal norms. All this predetermines the need for an active explanatory and educational work with the population of South-Eastern Ukraine, in conditions of the weak presence of the Ukrainian informational and cultural product and constant Russian informational pressure [13, p.50].

On June 21, 2007, by the decree of the President of the Russian Federation (No. 796), the Russian World Foundation was established. On the site of this fund, cells in 45 countries of the world, including in numerous cities of Ukraine, were designated. These Russian centers operated at libraries, universities, in theaters and even, sometimes, in local governments. And a peculiar consequence of this in 2014 was the seizure of the Crimea and administrative buildings in certain regions of eastern Ukraine by Russian troops and pro-Russian mercenaries, which, according to the provisions of international law, fully corresponds to the definition of political and military «aggression» $[14$, p. 367]. All this led to the fact that at this time in the occupied part of the Donbass, in particular - the Donetsk region, there is a noticeable decrease in the proportion of ethnic Ukrainians and the percentage of ethnic Russians is growing. In the part of the Donetsk region controlled by Ukraine, the development of the ethnocultural situation is determined by two factors: 1) actualization of national self-consciousness, patriotic feelings, growth of the level of national consolidation; 2) the migration flow of temporary and permanent population from the territories occupied by Russia, which in the average measurement according to ethnocultural characteristics has certain differences compared with the local population. Naturally, among the internally displaced people from Donetsk, Makeyevka, Gorlovka, Enakievo and other occupied cities, a relatively significant part is made up of ethnic Russians, citizens who do not speak Ukrainian fluently [15, p.129, 130]. A certain part of these ethnic Russians and Russian-speaking Ukrainians are now consciously and actively acquiring Ukrainian cultural and national identity.

In the context of the war unleashed against Ukraine, adherents of the «russian world» continue to develop this artificial doctrine, claiming «the for- 
mation of sufficiently powerful Russian frontiers in the Baltic States, Moldova, to a lesser extent in the Caucasus and Central Asian regions», special attention is paid to Belarus and Kazakhstan, and Ukrainian frontier was determined mainly [16]. When creating the so-called Novorossia and resolving the armed conflict in the east of Ukraine, the following were observed: destabilization of the eastern and southern regions of Ukraine by organizing mass anti-power protest actions, clashes with law enforcement agencies and supporters of the unity of Ukraine, and the seizure of administrative buildings; implementation of the «Crimean» scenario in the Donbas, including the establishment of control over part of their territories, the creation of «militia groups» from among the representatives of the Russian special services, criminalized law enforcement agencies and local pro-Russian forces; «Legalization» of the so-called Donetsk and Lugansk People's Republics (DNR and LNR) by means of the respective «referendums», as well as the «elections» of their «authorities». All this showed quite a significant preparation of the Russian Federation for complex aggression.

In an undeclared war against Ukraine, Russia is actively using methods of information-psychological warfare, trying to destroy the morale of military personnel and the civilian population of the Ukrainian state [17]. S. Gubsky noted that considerable historical experience and realities of Ukrainian-Russian relations after the annexation by Putin of Russia of the Crimea and the war it unleashed in the Donbas convincingly prove that the Russian ruling circles, regardless of their political coloration, always planted and carried out an aggressive, expansionist policy regarding their own neighbors. The existing theory of the so-called «Russian world» provides for the spread of Russian influence over all the territories where the Russian-speaking population lives. At the same time, Ukraine's plans in the Kremlin's leadership stand in a special place, given the historical relationship and the current desire of the Ukrainian people to finally break out of the tenacious embrace of the Russian Federation and take a worthy place among the civilized countries of the world. That is why the modern generation of Ukrainians desperately needs national consolidation, unity in the aspirations of the people and the political establishment, to adequately resist Russian aggression and negate the great-power plans of the modern «collectors of Russian lands» and restore the territorial integrity of the Ukrainian state $[18$, p.85, 86].

I. M. Dzyuba notes that on the territory of the socalled DNR and LNR there is a total «cleansing» of everything Ukrainian - from nationally oriented scientists, writers, journalists and cultural figures. At the same time, frank or hidden, ideologically disguised ethnocide (and lingvocid) in the Donetsk region, under various authorities (essentially never Ukrainian, there was), happened almost constantly [19, p.9, 10]. Therefore, the current situation with the Ukrainian identity in the occupied part of Donbass was only a continuation of the systematic planting of the «russian world» in Ukraine and the deformation of the cultural-national identity of Ukraine.

V. Ivanishin and J. Radevich-Vinnitsky convincingly prove that the destruction of a language (linguocide) is the most important condition for an ethnocide - the destruction of a nation as a cultural and historical community, its assimilation by another people (the nation). And almost all conquerors understand this. After all, linguocide is, as a rule, their strategic goal. Only tactics and forms of linguocidal implementation differ [9, p.115].

History quite clearly shows that even a multinational, imperial state usually defends the interests of a particular national group or people [20, p.33]. The ideologists of the «russian world» doctrine hypocritically assert some «symphony of the» Russian world "as an integration of peoples and cultures», and that «Russia has the precious experience of building just and peaceful interethnic relations, a multi-polar and multi-structured being» [16]. In fact, this doctrine was only a tool for essentially chauvinistic humiliation of peoples and nations.

Conclusions. It should be noted that modern wars and military-political conflicts have significant differences from previous models. At the same time, it should be noted that during world history, especially in the twentieth century, quite a lot of wars had signs of a hybrid and information-sabotage nature. Most wars are not only armed in nature, they often have a close connection with the psychological impact on people's minds through agitation, propaganda and other means of influence. This is especially true of the modern hybrid war unleashed by the Kremlin against Ukraine. Within the framework of this war, the Russian Federation uses a whole range of hybrid information technologies, in particular the doctrine of the «russian world», which encroaches on all territories where the Russian-speaking population exists. According to numerous statements by the adherents of the «russian world», the most purposeful object of the «russian world» planting was and remains Ukraine. At the same time, for centuries Ukrainians have been subjected to artificial deformation of cultural and national identity. And, in particular, the Ukrainians of the Donetsk region suffered the most. First of all, in this industrial-industrial region for Ukrainians, the problem of national identity was particularly acute, 
and usually boiled down to the following choice: either to Russify (primarily in terms of language), or to be always ready to fall under the repressive actions of Soviet power. Under such conditions, not only cultural identity, but also national consciousness, mentality and ethnopsychology of the Ukrainian nation were subjected to deformation.

Soviet totalitarianism, and especially the Holodomor of 1932-1933, in a large part of Ukraine, particularly in the Donetsk region, led to the loss of the majority of the Ukrainian national identity. This, in turn, has become a particularly favorable factor for planting the «russian world» there and the subsequent deformation of the Ukrainian cultural and national identity.

In our time, the situation with the Ukrainians in the occupied part of Donbass was only a continuation of the systematic planting of the «russian world» in Ukraine and the deformation of the cultural-national identity of Ukrainians. Therefore, the modern Russian-Ukrainian war, in fact, represents the newest stage of the national liberation struggle of Ukrainians for the preservation of national dignity and their own identity. And it is very important that at present a certain part of the ethnic Russian and Russian-speaking Ukrainians, who have left the occupied districts of the Donetsk region, consciously seek to acquire Ukrainian cultural and national identity.

In the further process of researching this topic, the origins and evolution of the idea of the urussian world» in Ukraine should be analyzed (using the example of the Donetsk region).

\section{Sources and literature}

1. Турченко Г. Ф. Південь в період Української революції: націєтворення чи національна дезінтеграція. Наукові праці історичного факультету Запорізького національного університету. Вип. 50. 2018. 56-69. DOI: 10.26661/swfh2018-50-003.

2. Сверстюк Є. На святі надій: Вибране. К.: Наша віра, 1999. 784 с.

3. Чикаленко Є. Х. Зібрання творів: в 7 т. К.: ТОВ компанія «РАДА», 2003. Т. 1: Спогади. Уривки з моїх споминів за 1917 p. 2003.432 c.

4. Ситник 0. М. Формування та еволюція ідеологічних концепцій національно-державницького спрямування в Україні (від початку XIX ст. - до 1939 р.): монографія. Донецьк: «Нуолідж» (Донецька філія), 2009. - 549 с.

5. Ситник 0. М. Сучасна російсько-українська війна 2014-2018 років як наслідок незавершеності національно-визвольних змагань 1917-1921 років. Війна на Донбасі. 2014-2016 рр.: зб. наук. праць за матеріалами Третьої Всеукраїнської наукової військово-історичної конференції «ВІЙНА НА ДОНБАСІ. 2014 - 2017 рр.», м. Київ, 19 квітня 2018 р. К., 2018 р. С. $194-197$.

6. Дзюба І. М. Донецька рана України: Історико-культурологічні есеї. К.: Інститут історії України НАН України, 2015. 78 c.

7. Гудзь В. В., Троїцька Т. С. Національна ідея в контексті українського менталітету. Науковий вісник Мелітопольського державного педагогічного університету. Історико-філософська серія. Вип. 4. 2005. 35-40.

8. Каганов Ю. 0. Національна ідентичність і радянська ідеологія: проблеми теоретичної концептуалізації. Наукові праці історичного факультету Запорізького національного університету. Вип. 31. 2011. С. 35-41.

9. Іванишин В., Радевич-Винницький Я. Мова і нація. Тези про місце і роль мови в національному відродженні України. 4-е вид., доп. Дрогобич: Видавнича фірма «Відродження», 1994. 218 с.

10. Турченко Г. Ф. Історична наука і сучасна гібридна війна Росії проти України. Наукові праці історичного факультету Запорізького національного університету. Вип. 46. 2016. С. 295-301.

11. Турченко Ф., Турченко Г. Проект «Новоросія» і новітня російсько-українська війна. К.: Інститут історії України НАН України, 2015. 166 с.

12. Залізняк Л. Л. Україна між Сходом і Заходом. Про витоки і суть російсько-української війни 2017 р. К.: Видавець Олег Філюк, 2017. 168 с.

13. Гай-Нижник П. Формування загальнонаціональної ідентичності українців в контексті сучасних викликів. Агресія Росії проти України: історичні передумови та сучасні виклики. Авт. кол.: П. П. Гай-Нижник, Л. Л. Залізняк, І. Й. Краснодемська, Ю. С. Фігурний, О. А. Чирков, Л. В. Чупрій. К.: «МП Леся», 2016. С. 32-54.

14. Гай-Нижник П. Агресія Росії проти України (2014-2016рр.): гібридна війна на поглинання та спроба знищення. Агресія Росії проти України: історичні передумови та сучасні виклики. Авт. кол.: П.П. Гай-Нижник, Л. Л. Залізняк, І. Й. Краснодемська, Ю. С. Фігурний, 0. А. Чирков, Л. В. Чупрій. К.: «МП Леся», 2016. С. 326-422.

15. Чирков 0. Етнічний чинник в агресії Російської Федерації проти України: етнокультурна історія південно-східних українських земель і сучасні маніпуляції Кремля. Агресія Росії проти України: історичні передумови та сучасні виклики. К.: «МП Леся», 2016. С. 109-133.

16. Аверьянов В. Доктрина Русского мира. URL: https://izborsk-club.ru/10269\#а4 (дата звернення: 18.02.2019).

17. Парубій А. Війна Росії проти України і світу. Українська Правда. 2014. 6 серпня 2014. URL: http://www.pravda. com.ua/articles/2014/08/6/7034046/ (дата звернення: 01.03.2019).

18. Губський С. Російський фактор у дестабілізації української державності (на прикладі антигетьманського повстання 1918 р. Російська окупація і деокупація України: історія, сучасні загрози та виклики сьогодення: Матеріали Всеукраїнської науково-практичної конференції (Київ, 2016 р.) / Упор. П. Гай-Нижник. К.: «МП Леся», 2016. С. 76-86.

19. Дзюба І. М. Донецька рана України: Історико-культурологічні есеї. К.: Інститут історії України НАН України, 2015. 78 c.

20. Лосєв I. XXI ст.: новітня бездержавність українців. Українознавчий альманах. Вип. 2. 2010. С. 33-36. 